\title{
"EVARISTO ERA MAIS FAMOSO POR SER GAY DO QUE POR SER ESTILISTA \\ DE MODA": UMA ANÁLISE CRÍTICA DO DISCURSO DA REPRODUÇÃO E SUBVERSÃO DE SEXUALIDADE E GÊNERO NO FILME "MACHO"
}

\author{
"EVARISTO WAS MORE FAMOUS FOR BEING GAY THAN BEING A FASHION \\ STYLIST": A CRITICAL DISCOURSE ANALYSIS OF THE REPRODUCTION AND \\ SUBVERSION OF SEXUALITY AND GENDER IN THE FILM "MACHO"
}

\author{
Paula Fernandes Furbino Bretas \\ Instituto Federal de Brasília \\ paulaffb@gmail.com \\ Henrique Luiz Caproni Neto \\ UFMG \\ henriquecap_adm@yahoo.com.br \\ Marcos Moura-Paula \\ Instituto Federal de Brasília \\ mahjump@gmail.com
}

Submissão: $14 / 10 / 2019$

Aprovação: 27/04/2021

\begin{abstract}
RESUMO
Buscamos analisar a reprodução e a subversão do binário de gênero e sexualidade no filme "Macho". Discutimos sobre a constituição do sujeito, resistências e heteronormatividade em uma perspectiva feminista. Trata-se de uma metodologia qualitativa com análise fílmica e análise crítica do discurso. Trabalhamos com três categorias de análise: "Evaristo era mais famoso por ser gay do que por ser estilista de moda": a constituição do sujeito; "Não há o gene gay. É uma preferência sexual. E mais, é uma experiência temporal": a reprodução e a subversão do discurso da heteronormatividade; "Às vezes, eu me pergunto: mas para quê Evaristo? Por que não se tornou boxeador como seu pai?": a reprodução e a subversão do discurso binário de gênero nas relações sociais de trabalho. Como resultados, analisamos como os discursos da meritocracia, da sexualidade e da heteronormatividade atravessam a constituição do sujeito mais famoso por ser gay do que por ser estilista de moda. Por fim, como o binário de gênero possui relação com a divisão sexual generificada do trabalho e as características específicas na moda, percebemos uma construção discursiva instável, cujos sujeitos performam diversos gêneros e por vezes reproduzindo e subvertendo a heteronormatividade e o binário de gênero.
\end{abstract}

Palavras-Chave: gênero, sexualidade, análise fílmica, análise crítica do discurso, performance 
ABSTRACT

We seek to analyze the reproduction and subversion of the gender and sexuality binary in the movie "Macho". We discuss the constitution of the subject, resistance and heteronormativity in a feminist perspective. This is a qualitative methodology with film analysis and critical discourse analysis. We work with three categories of analysis: "Evaristo was more famous for being gay than for being fashion stylist": the constitution of the subject; "There is no gay gene. It's a sexual preference. Moreover, it is a temporal experience ": the reproduction and subversion of heteronormativity discourse; "Sometimes, I ask myself: but for what Evaristo? Why did you not become a boxer like your father? ": The reproduction and subversion of binary gender discourse in social relations of work. As results, we analyze how the discourses of meritocracy, sexuality and heteronormativity cross the constitution of the subject more famous for being gay than for being fashion stylist. Finally, as the gender binary is related to the gendered sexual division of labor and the specific characteristics in fashion, we perceive an unstable discursive construction, whose subjects perform different genders and sometimes reproducing and subverting heteronormativity and gender binary.

Keywords: gender, sexuality, film analysis, critical discourse analysis, performance

\section{Introdução}

O cinema pode ser considerado uma das mais elaboradas formas de arte (utiliza-se de sons, imagens, diálogos, etc.) que permitem apreender a dinâmica das relações sociais e aplicar conceitos científicos prévios, como também sugerir desenvolvimentos teóricos. Suas narrativas são construídas a partir do mundo real (MACHADO; IPIRANGA; MATOS, 2013), possibilitando que vejamos como significados e simbolismos transitam nas tramas. Ao representar o real por meio da ficção, o cinema permite também jogar com esse real, propondo uma narrativa com pretensões de verdade (MEDEIROS; VALADÃO JÚNIOR; POSSAS, 2015). Dessa forma, os filmes podem, por exemplo, a partir do conhecimento teórico prévio de quem os assiste, despertar a atenção do espectador para diferentes questões que perpassam as relações sociais e organizacionais retratadas na obra (p.ex., ARAÚJO, TOMEI, 2012; FERRAZ et al., 2017; MORAES; GOMES, HELAL, 2016).

Não obstante, é importante ressaltar que o cinema como linguagem pode ir além da representação da realidade e que podemos compreender os fenômenos sociais pelos discursos. Fairclough (2001) entende o discurso como uma prática social capaz tanto de reproduzir quanto de transformar realidades sociais. Assim, o discurso é um modo de ação, pois constitui o mundo significado. É nesse caráter produtor que compreendemos o uso da linguagem como construtora da realidade e não meramente como ferramenta útil para a descrição do real (FAIRCLOUGH, 2001). A partir da análise da prática discursiva, Fairclough (2001) propõe que não apenas se compreenda o modo como os sujeitos produzem seu mundo ordenado, mas também que se perceba como as práticas dos membros de uma comunidade são moldadas por estruturas sociais, relações de poder e pela natureza da prática social e como essas práticas têm resultados e efeitos sobre as estruturas, relações e lutas sociais.

Entendendo, dessa forma, o cinema como discurso e modo de significação do mundo, Zanello (2018) elenca uma série de exemplos de filmes da Disney que funcionam como tecnologias de gênero ao interpelar os sujeitos na constituição de sua subjetividade. Se filmes como "A Pequena Sereia" ou "A Bela e a Fera" reproduzem pedagogias afetivas que colocam o amor como principal elemento identitário da subjetividade das mulheres de uma maneira heteronormativa hegemônica, isso nos leva crer a nas possibilidades de resistência e mudança social pelo/no discurso (FAIRCLOUGH, 2001). 
Nesse contexto, deparamo-nos com o filme "Macho", um longa-metragem mexicano. O filme trata da vida pessoal e profissional do estilista de moda Evaristo, que tinha uma carreira internacional consolidada. A performance de gênero feminina de Evaristo era um chamariz midiático para a sua vida profissional, o que o levava a crer que demonstrar ser gay era a fonte de seu sucesso. Portanto, de um lado, ao se relacionar com mulheres, ele se escondia para que pudesse manter sua fama, e por outro lado, para que não fosse considerado uma ameaça aos relacionamentos héteros de suas clientes/modelos. No decorrer do filme, ele experimenta diferentes práticas sexuais, hétero, homo e bissexuais, passando por crises de identidade, conflitos na carreira e sendo alvo de críticas da sociedade. A película trouxe, por meio da arte, uma possibilidade de vislumbrar realidades alternativas à matriz heteronormativa e ao binarismo de gênero. Diante disso, chegamos à seguinte problematização: Como os filmes, entendendo-os como discurso e prática social, podem se constituir como formas de subversão das normas de gênero no contexto do trabalho? Como esses mesmos filmes podem também se constituir como formas de reprodução dessas normas?

Então, nosso objetivo neste artigo é analisar a reprodução e a subversão dos binários de sexualidade e gênero no filme "Macho". Para tanto, faremos uma revisão teórica sobre a constituição do sujeito numa perspectiva feminista e sobre a matriz heteronormativa e o binário de gênero, buscando subsidiar a análise das identidades, convenções (sistemas de crença) e relações sociais de trabalho, prazer e afeto que o filme "Macho" apresenta. Em termos metodológicos, esta é uma pesquisa qualitativa que se vale das técnicas de análise fílmica e análise crítica do discurso para analisar seu objeto empírico, o filme "Macho".

Nesse contexto, sexualidade e gênero são temas há muito tempo estudados na saúde, na psicologia, na sociologia e na educação no Brasil. Contudo, a analítica queer tem começado a ser utilizada nos estudos organizacionais brasileiros para analisar formas de opressão relacionadas especialmente ao gênero, à sexualidade e à identidade (SOUZA; CARRIERI, 2010). As teorias pós-estruturalistas de gênero e queer se sobrepõem e dialogam entre si, focando nos processos de desconstrução de identidade, da heteronormatividade e do binário sexo/gênero como forma de demonstrar que tais processos são discursivos e se desenrolam em meio a relações de poder. Destaca-se ainda a busca de construções identitárias alternativas que tornam a analítica queer distintiva, possibilitando novos focos e a ampliação das perspectivas feministas.

Nos estudos organizacionais, heteronormatividade e binário de gênero pouco aparecem como objetos de investigação de pesquisadores brasileiros. Souza e Carrieri (2010) introduziram a temática no campo a partir da apresentação de como a analítica queer pode ser um referencial de desconstrução de discursos binários que se deslocam da realidade social e acabam por contestar a discriminação no local de trabalho. Nessa direção de crítica à heteronormatividade nas organizações, Carrieri, Aguiar e Diniz (2013) estudaram o sofrimento de trabalhadores homossexuais vítimas de assédio moral e violência simbólica. Já Souza e Pereira (2013) estudaram a discriminação de homossexuais por outros homossexuais e identificaram que a heteronormatividade também é reproduzida por esses em meio às relações de gênero. Recentemente, Souza (2017, p. 319) revisou a teoria queer e sua relação com identidade nos estudos organizacionais, demonstrando as identidades como dispositivos de poder "que organizam a sociedade por meio do estabelecimento de sistemas hegemônicos de lógica binária sobre o que é normal e o que é anormal, construindo categorias discursivas, identidades e hierarquias entre sujeitos".

Portanto, percebemos que as pesquisas sobre heteronormatividade nos Estudos Organizacionais focaram na discriminação e na violência e que abordar possibilidades de resistências, vislumbrando práticas alternativas à matriz heteronormativa se mostrou como uma lacuna de pesquisa. Justifica-se essa pesquisa, portanto, por sua contribuição analítica sobre como os discursos desconstroem e reproduzem a heteronormatividade no contexto da 
divisão sexual do trabalho, ampliando a discussão de gênero e sexualidade nos Estudos Organizacionais.

\title{
2. Referencial Teórico
}

\subsection{Sobre a constituição do sujeito discursivo e resistências numa perspectiva feminista}

Os trabalhos pós-estruturalistas sobre gênero, geralmente denominados analítica queer, são heterogêneos não possuindo uma agenda homogênea entre seus autores. Todavia, eles possuem alguns pontos em comum como a crítica à concepção humanista do sujeito (SOUZA, 2016). Em detrimento de considerar a identidade e a agência como características antropológicas, uma perspectiva pós-estruturalista considera ambas socialmente e discursivamente (re)produzidas nas/pelas relações de poder. É exatamente essa ênfase na produção discursiva da identidade que politiza a agência (BENDL; FLEISCHMANN, WALENTA, 2008).

Em oposição ao sujeito humanista e transcendental, os autores pós-estruturalistas questionaram o sujeito cartesiano-kantiano, "autônomo, livre e transparentemente autoconsciente, que é tradicionalmente visto como a fonte de todo o conhecimento e da ação moral e política" (PETERS, 2000, p. 33), em prol de um

\begin{abstract}
[...] sujeito em toda a sua complexidade histórica e cultural - um sujeito "descentrado" e dependente do sistema linguístico, um sujeito discursivamente constituído e posicionado na intersecção entre as forças libidinais e as práticas socioculturais. O sujeito, outra vez sob a influência de Niestzche, é visto, em termos concretos, como corporificado e generificado, um ser temporal, que chega fisiologicamente falando, à vida e enfrenta a morte e a extinção como corpo, mas que é, entretanto, infinitamente, maleável e flexível, estando submetido às práticas e às estratégias de normalização e individuação que caracterizam as instituições modernas (PETERS, grifos do autor, 2000, p. 33).
\end{abstract}

Portanto, o sujeito não preexiste, mas surge em um campo de batalhas resultando de relações de poder (FOUCAULT, 2014). Souza, Souza e Silva (2013, p. 213) esclarecem que, para o pós-estruturalismo, o sujeito não é autônomo, nem determinado pela estrutura, mas sim "constituído e constituidor de sua subjetividade, contingenciada por discursos e relações de poder, inserida em uma rede complexa de narrativas e práticas instáveis".

Para compreender esse processo de constituição do sujeito, portanto, mais do que se perguntar por que dominar os outros, a análise deve buscar entender como essa sujeição funciona no presente (DÍAZ, 2012). Nessa direção, nos Estudos Organizacionais, defende-se que se estude as diversas forças organizacionais que atravessam o sujeito ao invés de se enfatizar o homem como centro da análise:

[...] enxergando-se o homem como um sujeito atravessado por diversas forças, são exatamente tais forças que devem ser analisadas e entendidas, pois são elas que atuam sobre os trabalhadores e os constituem como sujeitos. [...] Portanto, há uma inversão de pólos em que o mais importante não é estudar o homem, mas, sim, as redes de força organizacionais que o moldam e o desmoldam a todo tempo. $\mathrm{O}$ homem é visto apenas como um efeito desse processo, como se fosse apenas uma grande tela de cinema na qual ocorre a projeção e se dá visibilidade a todas essas forças, não sendo, assim, concebido como um sujeito autônomo (SOUZA, MACHADO, BIANCO, 2008, p. 83).

Seguimos Souza, Costa e Pereira (2015) quando consideram as organizações de uma forma ampla, não se limitando à empresa ou entidade, mas como um processo de organizar (organizing) os corpos, os gestos, as subjetividades, a vida, etc., que não acontecem somente 
nas relações de trabalho ou dentro das empresas. Portanto, neste artigo, problematizamos tanto essa universalidade do sujeito quanto essa complexa rede de forças que o atravessam numa perspectiva feminista, na defesa de que o sujeito, mesmo moldado histórica e discursivamente, tem possibilidade de ação transformadora de suas próprias práticas, em um processo de reprodução e subversão dos binários de gênero e de sexualidade. Isso significa que o sujeito-agente pode se conformar às formações discursivas/sociais que o compõem, como também a elas resistir, ressignificando-as e reconfigurando-as (MELO, 2009).

Coadunamos com a crítica de Mariano (2005) quando diz que os ideais iluministas, além de atribuir homogeneidade e unidade ao sujeito universal, veem essa universalidade como masculina. Assim, na perspectiva feminista, o sujeito é constituído por múltiplas posições, contingentes e contraditórias e "descentrar" o sujeito é evidenciar que ele estava marcado por particularidades que se pretendiam universais, privilegiando, muitas vezes, o homem "branco", heterossexual, rico, sem deficiências, europeu, cristão, casado e provedor da família.

Thomas e Davies (2005) ressaltam que os estudos feministas têm uma longa história tratando das políticas de diferenças e desenvolvendo uma teorização densa e detalhada sobre sujeito, agência e resistência, uma vez que a emancipação e a transformação social são fundamentais para esses. Contudo, não se pretende encontrar uma relação causa-efeito entre ideologia-dominação-alienação, pois o pós-estruturalismo não entende o sujeito como alienado cuja emancipação se dá pela sua conscientização pela razão, pois ele sempre será atravessado por relações de poder. Na presente abordagem, existem emancipações, no plural, já que o pós-estruturalismo aceita a "pluralidade e a particularidade das demandas emancipatórias constituídas por contingências históricas" (SOUZA; SOUZA; SILVA, 2013, p. 211). Destaca-se a contribuição da teoria feminista para os estudos organizacionais, evidenciando que o contexto das opressões e das resistências não se relaciona somente com a luta de classes, mas, igualmente, com gênero, raça/cor, corpo, etnia e sexualidades ( HARDING; FORD, FOTAKI, 2012; THOMAS; DAVIES, 2005).

Butler (1993) entende o sujeito como uma categoria discursiva estabelecida por meio de relações de exclusão e sempre em busca de reconhecimento social, atravessado por relações de poder e de investimentos emocionais, concomitantemente, assujeitado pelas interpelações e normas de gênero, mas que faz do discurso seu meio de resistência e subversão. Evidenciando o gênero como dispositivo, norma citacional da qual não podemos fugir, mas que pode ser ressignificado e contestado, pois a desconstrução da distinção sexo/gênero mostra que a suposta coerência entre desejos, práticas sexuais e identidades é uma noção fabricada nas e pelas relações de poder (FOUCAULT, 1988).

Para compreender essas estruturas sociais contemporâneas no que tange ao gênero e à sexualidade e as relações de poder subjacentes, abordaremos na próxima seção a matriz heteronormativa e o binário de gênero.

\subsection{A matriz heteronormativa e o binário de gênero}

A ordem social não é diferente de uma ordem sexual inscrita em um binarismo hétero/homo ou masculino/feminino, tornando a heterossexualidade um dispositivo de poder normativo, naturalizante e compulsório. A heterossexualidade como modelo social pode ser dividida em dois momentos: um em que é entendida de forma compulsória, pura e simples; e outro no qual vamos para o domínio da heteronormatividade. Neste último, com a despatologização e descriminalização da homossexualidade a partir da segunda metade do século XX, a heteronormatividade é enfatizada como um modo de controle e de normalização, inclusive de gays e lésbicas, não para que se "tornem heterossexuais", mas para que vivam como tal (MISKOLCI, 2009) e que adotem os "atributos" de gênero exaltados socialmente. 
Algumas considerações são relevantes quanto aos termos heterossexualidade compulsória, heterossexismo e heteronormatividade. $\mathrm{O}$ termo heterossexualidade compulsória foi cunhado por Adrienne Rich, em 1980, em uma perspectiva feminista lésbica, que abrange o fortalecimento das instituições que controlam as mulheres, como a maternidade patriarcal, a exploração econômica, a família nuclear e a heterossexualidade compulsória, por meio de uma legislação de imagens midiáticas e de esforços de censura (RICH, 2010).

O termo heterossexismo diz respeito à pressuposição de que todos são ou deveriam ser heterossexuais, a um sistema ideológico produtor de privilégios para pessoas que estão de acordo com as normas heterossexuais, e exclui aquelas que não estão (MISKOLCI, 2012; SOUZA; PEREIRA, 2013; WELZER-LANG, 2001). Podemos conceituar a heteronormatividade como um fenômeno que vai além do "aperçu de que a heterossexualidade é compulsória..." (MISKOLCI, 2012, p. 156). Nesse sentido, Foucault (1988) salienta que, a partir do século XVIII, há uma verdadeira explosão discursiva em torno do sexo no campo de exercício do poder, de modo que se deve gerir o sexo, torná-lo útil, regulá-lo para o bem de todos. Logo, tal como um dispositivo de sexualidade produzido, social e discursivamente em prol da heteronormatividade.

A heteronormatividade é um mecanismo mais amplo de poder e de hierarquização entre os gêneros e as sexualidades, um dispositivo histórico para assujeitar e normalizar todos para serem heterossexuais ou organizarem suas vidas a partir do modelo supostamente coerente, superior e "natural" da heterossexualidade (FOUCAULT, 1987; MISKOLCI, 2012; SOUZA; PEREIRA, 2013) ou, ainda, como "enquadramento de todas as relações - mesmo as supostamente inaceitáveis entre pessoas do mesmo sexo - em um binarismo de gênero que organiza suas práticas, atos e desejos a partir do modelo do casal heterossexual reprodutivo" (PINO, 2007, p. 160).

Este modelo aliado ao sexismo em consequência do regime binário de gênero e da sexualidade, busca tornar as feminilidades e masculinidades essencializadas e mutuamente excludentes, tomadas como parâmetros de normalidade. Desse modo, qualquer expressão da sexualidade e gênero é valorada, cerceando possibilidades de diferenciação na apropriação pessoal, social, cultural e histórica do feminino e do masculino por pessoas de ambos os sexos (LIONÇO; DINIZ, 2008). Assim, "a regulação binária da sexualidade suprime a multiplicidade subversiva de uma sexualidade que rompe as hegemonias heterossexual, reprodutiva e médico jurídica" (BUTLER, 2003, p. 41).

A heteronormatividade e o binarismo de gênero repercutem em práticas discriminatórias, algo na direção do que Welzer-Lang (2001) propõe ao conceituar a violência homofóbica, enfatizando que esta engessa as fronteiras entre os gêneros em um paradigma naturalizado em que se privilegia o masculino à custa do feminino: como a discriminação entre pessoas que expressam qualidades social e culturalmente atribuídas ao outro gênero. Assim:

A coerência ou a unidade interna de qualquer dos gêneros, homem ou mulher, exigem assim uma heterossexualidade estável e oposicional. Essa heterossexualidade institucional exige e produz, a um só tempo, a univocidade de cada um os termos marcados pelo gênero que constituem os limites da possibilidade de gênero no interior do sistema de gênero binário oposicional. Essa concepção de gênero não só pressupõe uma relação causal entre sexo, gênero e desejo, mas sugere igualmente que o desejo reflete ou exprime o gênero e que o gênero reflete ou exprime o desejo [...] (BUTLER, 2003, p. 45).

Butler (2003) ressalta que os gêneros proporcionam a possibilidade de humanizar os indivíduos, tornando-os sujeitos. Dessa forma, quem não desempenha corretamente seu 
gênero em um sentido normativo, cultural, político e social é alvo de variadas punições e visto como abjeto, tendo sua própria humanidade questionada em decorrência da matriz heteronormativa. Com base nessa explanação sobre a matriz heteronormativa, para Butler (1993, 2003, 2004) o gênero está além de um quadro que se caracteriza por masculinidades e feminilidades, sendo, de fato, uma norma, um dispositivo ou aparato de poder e de normalização que confere ou não humanidade a determinado corpo. Assim, o gênero estabelece e requer seu próprio regime regulador e disciplinar específico, de modo que nos concentramos em seu ponto crítico, em que as matrizes binárias são contingentes e que as permutações de gênero que não se encaixam no binarismo são tanto parte do gênero como seu exemplo mais normativo. Isso afasta a ideia de que o gênero seria um modelo ao qual os sujeitos tentam aproximar-se, uma vez que transgêneros mostram que o gênero está além do binarismo naturalizado (BUTLER, 2004).

\section{Metodologia}

As várias produções artísticas possibilitam tanto o entretenimento quanto a reflexão e a crítica ao mundo "real". Os filmes, através de suas histórias, narrativas, conflitos, possibilitam ao sujeito experimentar realidades alternativas, haja vista que o filme nos apresenta um ponto de vista que somos convidados a analisar diante de nossas experiências e valores. Os filmes podem ser considerados como ficções divertidas, como reflexos da realidade ou como artefatos culturais que moldam e constituem nossa compreensão da vida social e organizacional (HUCZYNSKI, BUCHANAN, 2004).

Penafria (2009) ressalta que analisar um filme é decompor esse filme, mesmo não existindo uma metodologia universalmente aceita, é usual que haja duas etapas nessa análise: decompor ou descrever o filme e, em seguida, estabelecer e descrever as relações entre os elementos decompostos, ou seja, interpretar. Dessa forma, trata-se de um processo de decomposição e de reconstrução do filme. Ainda nota que a análise de filmes deve considerar os objetivos estabelecidos a priori e que se trata de uma atividade que demanda uma observação rigorosa, atenta e detalhada.

Assim, em conformidade com a literatura (PANAYIOTOU, 2010, 2015), consideramos que os filmes são narrativas visuais que podem ser analisados seguindo alguns passos. $\mathrm{O}$ primeiro foi assistir ao filme várias vezes fazendo anotações de sua estrutura narrativa. Assim, assistimos individualmente o filme diversas vezes, fizemos anotações e discutimos coletivamente sobre a narrativa, personagens, performances, conflitos e cenas. O segundo esteve relacionado a "ler" e "reler" criticamente a narrativa visual dando atenção ao que foi dito e como foi dito, pausando o filme quantas vezes fossem necessárias para tomar notas do que foi falado. Isso também foi realizado justamente para observar, com detalhes e atenção, diálogos relevantes, performances de gênero, expressões de sexualidade, conflitos bem como para anotar cenas de destaque. $\mathrm{O}$ terceiro tratou de analisar as imagens visuais que circundam os construtos linguísticos, tais como as formas de se vestir e movimentar-se, a forma de deslocamento entre os espaços, os locais de encontros e a decoração utilizada. Esse terceiro passo foi relevante tendo em vista cenas e imagens que nos chamaram atenção especialmente para as relações entre gênero e os espaços organizacionais. Por fim, o quarto passo consistiu em interpretar o que foi coletado nos passos anteriores a partir da análise crítica do discurso.

Para este artigo, utilizamos recursos da Análise Crítica do Discurso (ACD) proposta por Fairclough (2001). Ela é baseada numa noção de tridimensionalidade do discurso, isto é, o discurso pode ser analisado como texto, como prática discursiva e como prática social, sendo a concepção de discurso considerada um modo de ação historicamente situado em que estruturas organizam produções discursivas e, por outro lado, enunciados novos são ações 
individuais sobre tais estruturas, podendo mantê-las ou transformá-las (FAIRCLOUGH, 2001; RESENDE; RAMALHO, 2006).

Fairclough (2001) compreende texto como linguagem falada ou escrita. Contudo, os textos, unidade mínima de análise dos discursos, são aqui entendidos de forma que ultrapassam o sentido como puramente produções escritas. Além da linguagem verbal, oral e escrita, são incluídos no sentido os textos imagéticos e os multimodais (linguagem verbal, visual e efeitos sonoros) (RESENDE, 2008). Em suma, neste artigo, a análise textual será organizada a partir das seguintes categorias analíticas: vocabulário, estrutura textual e ethos (FAIRCLOUGH, 2001).

A segunda dimensão da ACD é a análise de práticas discursivas. Focaliza os processos de produção, distribuição e consumo textual. A produção e o consumo possuem natureza sociocognitiva por serem baseadas em estruturas e convenções sociais interiorizadas. Uma das preocupações da análise de práticas discursivas é especificar as ordens de discurso em que se baseiam e como ocorre a produção e a interpretação dos sentidos, de maneira que não apenas se compreenda o modo como os sujeitos produzem seu mundo ordenado, mas também que se perceba como as práticas dos membros de uma comunidade são moldadas por estruturas sociais, relações de poder e pela natureza da prática social de forma inconsciente. (FAIRCLOUGH, 2001).

A análise da prática discursiva terá foco nas condições da prática discursiva e na interdiscursividade. A primeira refere-se à recorrência explícita de outros textos. A última está ligada à "constituição heterogênea de textos por meio de elementos (tipos de convenção) das ordens de discurso (interdiscursividade)" (FAIRCLOUGH, 2001, p. 114).

Entendendo o discurso como prática social, esta seria a dimensão na qual ações reiteradas podem reproduzir ou transformar a ordem social. É a instância na qual se analisa a mudança social, percebendo como as ideologias, significações de mundo que são construídas em várias dimensões da prática discursiva, desafiam ou reproduzem discursos hegemônicos ou as ordens de discurso existentes (FAIRCLOUGH, 2001).

\section{Análise e Discussão dos Resultados}

Ao analisar o filme, inicialmente, fizemos uma análise sobre a constituição do sujeito assujeitado, não autônomo, para fundamentarmos a nossa discussão que não se situa no âmbito do indivíduo, e contextualizamos as condições de produção e subversão das práticas discursivas.

Ao fazer a análise tridimensional do discurso, destacamos as seguintes ordens de discurso: discurso da heteronormatividade e discurso binário de gênero. Essas práticas discursivas são materializadas nos textos que serão analisados (diálogos e imagens), são interpeladas por outras ordens de discurso em um processo de interdiscursividade e constituem o mundo social ao significá-lo (FAIRCLOUGH, 2001).

Enquanto prática social, esses discursos são modos de ação que constituem identidades sociais, relações sociais e sistemas de conhecimento e crença (FAIRCLOUGH, 2001). Portanto, problematizamos as identidades homo, hétero e bissexual, suas relações sociais de trabalho, prazer e afeto e os sistemas de conhecimento e crença vigentes que compreendem gênero por uma perspectiva biológica. Entendemos que o deslocamento nas ordens discursivas podem fornecer elementos para a crítica da hegemonia em torno da heteronormatividade e do binário de gênero, demonstrando possibilidades de mudança social e nas organizações.

4.1 "Evaristo era mais famoso por ser gay do que por ser estilista de moda": a constituição do sujeito 
Inicialmente, como apresentação das condições sociais das práticas discursivas, descrevemos o enredo do filme: Evaristo é um estilista famoso que construiu um império no ramo da moda. Sua vida profissional e pessoal era constante pauta da imprensa local de seu país, já que tinha uma reputação internacional consolidada. Assim, não lhe faltavam questionamentos sobre sua sexualidade e suas criações. Evaristo se dizia gay para o mundo e suas roupas e gestos possuíam características convencionalmente femininas. Contudo, praticava, secretamente, atos convencionalmente heterossexuais, pois acreditava que sua fama estava associada não somente ao seu trabalho, mas também à sua sexualidade e gênero. Além disso, aproveitava-se do fato para se relacionar com mulheres comprometidas, posto que não seria motivo de preocupação para seus respectivos cônjuges já que, para todos os efeitos, seria gay.

Tendo sua vida sendo transformada em documentário durante o filme e diante de críticas cada vez mais frequentes sobre sua sexualidade, sua sócia lhe propõe a solução para os problemas: se ele tivesse um namorado, comprovaria ao mundo sua sexualidade e os negócios não seriam afetados. Evaristo se utiliza dos aparatos da mídia e da moda para demonstrar sua relação amorosa com um namorado (Sandro), mas essa relação estava permeada de mentiras e preconceitos. Não obstante, numa mistura entre prazer, sucesso, afeto, raiva, preconceito, entre outros sentimentos, uma outra relação vai se construindo ao longo da trama. Ao mesmo tempo em que Evaristo percebia, relutantemente, a possibilidade de um afeto por Sandro, Sandro também construía uma relação afetiva com Vivi (amante de Evaristo). Nesse emaranhado de relações pessoais, a fama de Evaristo se transformava negativamente e os movimentos LGBTQ protestam contra as atitudes do estilista, acusandolhe de ter se aproveitado das minorias para se favorecer. Numa reviravolta, Sandro expõe sua intimidade com Evaristo publicamente, o que faz o público perceber que nem tudo fora mentira. Assim como não foram mentiras as relações entre Evaristo e Vivi e entre Vivi e Sandro. No final, os três se casam.

Em um nível macro, analisamos as práticas discursivas, isto é, a produção, a distribuição e o consumo de textos. Para tanto, recorremos à dimensão de análise da interdiscursividade, pois a partir dela podemos analisar a constituição heterogênea dos textos por tipos de convenções das ordens de discurso, seja de forma a naturalizá-las ou transformálas (FAIRCLOUGH, 2001).

Em uma das primeiras cenas do filme, Evaristo é recepcionado com palmas na sua própria empresa, cercado por jornalistas que estavam documentando seu processo criativo (e sua vida), aos gritos de "Bravo! Bravo". Nessa prática, percebemos a presença de algumas convenções sociais, como sucesso, fama e exposição midiática, que constituem as práticas discursivas do sujeito, bem como constituem sua própria subjetividade. Evaristo, a todo momento, exalta tudo o que conquistou ao longo de vinte anos ao mesmo tempo em que reclama das dificuldades da profissão como forma de demonstrar que essa conquista não foi fácil. Assim, percebemos a constituição da ordem de discurso da "meritocracia".

Entretanto, ao produzir esse texto, é necessário observar para quem ele fala. $\mathrm{Na}$ distribuição de textos, as pessoas ligadas ao mundo da moda seguem convenções próprias que também moldam as práticas discursivas. Meritocracia numa indústria de bens de capital possui sentidos diferentes daqueles construídos na indústria da moda. Enquanto na primeira, o sucesso está relacionado a características consideradas masculinas como racionalidade e força; na segunda, ele se associa à emoção, à arte e à sensibilidade, características tidas como femininas. É nessa relação de poder entre gêneros que Evaristo naturaliza as convenções ao se dizer gay e praticar gestos e atitudes efeminadas, inserindo a ordem de discurso da "sexualidade" na disputa que atravessa o sujeito, como demonstra a figura 1. 


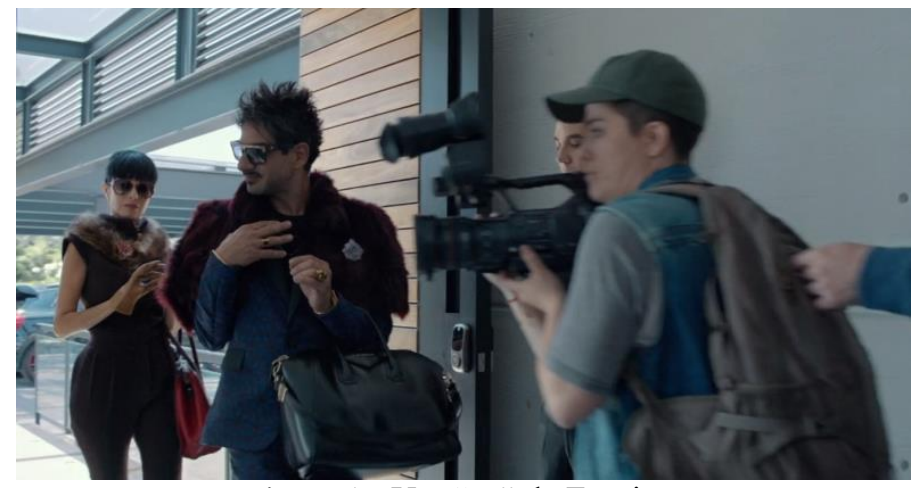

Figura 1 - Um "eu" de Evaristo

Em um espaço temporal, Evaristo se diz gay, mas tem práticas heterossexuais. Mais do que isso, ele reproduz uma série de convenções relacionadas à sexualidade, como a prática de virilidade ao ter feito sexo com 322 mulheres e ser desejado por todas, naturalizando a ordem de discurso da "heteronormatividade".

Em outro, Evaristo se diz hétero, mas tem práticas homossexuais, como quando se relaciona com Sandro. Mais do que isso, Evaristo percebe que pode alterar a lógica de seu processo criativo profissional, o qual só funcionava com a inspiração de uma diva e um animal. Evaristo troca um animal por vários animais e nomeia Sandro de Sindy para transformá-lo em sua diva, práticas que retiram do gênero a estabilidade, subvertendo-a.

Logo, com base na interdiscursividade, percebemos a heterogeneidade que caracteriza a constituição dos textos (enredo do filme), pois várias ordens de discursos (meritocracia, masculinidade, feminilidade, heteronormatividade, entre outras) estão em constante disputa na constituição da subjetividade dos sujeitos e na sua própria constituição. O sujeito não é um ser racional pré-existente, mas se constitui a partir do e no discurso, sendo atravessado por diversas forças que tornam a subjetividade uma complexa rede de práticas instáveis que ora naturalizam, ora subvertem a ordem vigente.

4.2 "Não há o gene gay. É uma preferência sexual. E mais, é uma experiência temporal": a reprodução e a subversão do discurso da heteronormatividade

Neste tópico, a base da ACD é a prática social haja vista a heteronormatividade como discurso hegemônico que vai sendo reproduzido e subvertido na sociedade em meio às relações de poder. Assim, Evo segue a recomendação de Alva para manter seu império, começa a paquerar Sandro e o convida para ir à Colômbia para uma sessão de fotos, como seu namorado. No decorrer da sessão, o fotógrafo pede que se aproximem e Sandro beija Evo. A reprodução da heteronormatividade leva Evo à uma crise. Ele saiu correndo em gritos e Alva vai atrás dele:

\footnotetext{
-Alva: Você está bem?

-Evo: Como posso estar bem? Um homem acaba de me beijar na boca. Estou em choque.

-Alva: eu sei, Evo, mas isso não é nada.

-Evo: como não é nada, acaba de arrebentar minha identidade sexual. Senti claramente como se algo rompeu dentro de mim. Algo se soltou, fez clique. Não! Vão nascer mamas em mim. Meu pênis vai cair. (risos de Alva). Não ria, maldita. Veja, sinta como meu coração. Sinta como palpita. Como um tambor.

-Alva: Você acaba de salvar nosso império Evaristo. Celebra a diversidade.

-Evo: Não sou homofóbico. Mas também não quero que a diversidade me beije na boca. (Trecho 1)
} 
Perceba acima como a heterossexualidade é uma norma, um discurso materializado no texto (diálogo), uma forma de ação imposta, reproduzida e incorporada nos corpos de modo que um beijo entre dois homens desestabiliza a identidade de Evo "como se algo rompeu dentro de mim".

Pensando especificamente na relação de Evo e Sandro: durante boa parte do filme, Evo, apesar de se comportar de modo feminino, quase sempre reproduz um discurso masculinista em direção à hegemonia heteronormativa como prática social como quando trata Sandro por diversas vezes no feminino utilizando léxicos femininos ou o apelidando de Sindy.

Enquanto Sandro, mesmo se expressando de modo masculino, exalta atributos considerados femininos quanto à emoção, à fragilidade, ao carinho e ao cuidado. Desse modo, essas práticas são ambivalentes (BUTLER, 2004) em vários discursos do filme.

Evo em suas expressões de gênero contesta a heteronormatividade, mesmo que de modo precário, quebrando a coerência entre genitália e comportamento, mas em seus discursos com Sandro ele a reproduz se assujeitando às normas. Já Sandro usualmente enfatiza a masculinidade em suas expressões de gênero, mas em sua psique, ele desloca a norma lidando positivamente com sua sexualidade quebrando a coerência entre genitália, desejo e prática sexual (BUTLER, 2003). Veja adiante duas cenas de Sandro: uma em que ele salva Evo de um sequestro, o que vai em direção ao comportamento másculo; e outra em que cuida de Evo monstrando seu rompimento com a heteronormatividade (BUTLER, 2003).

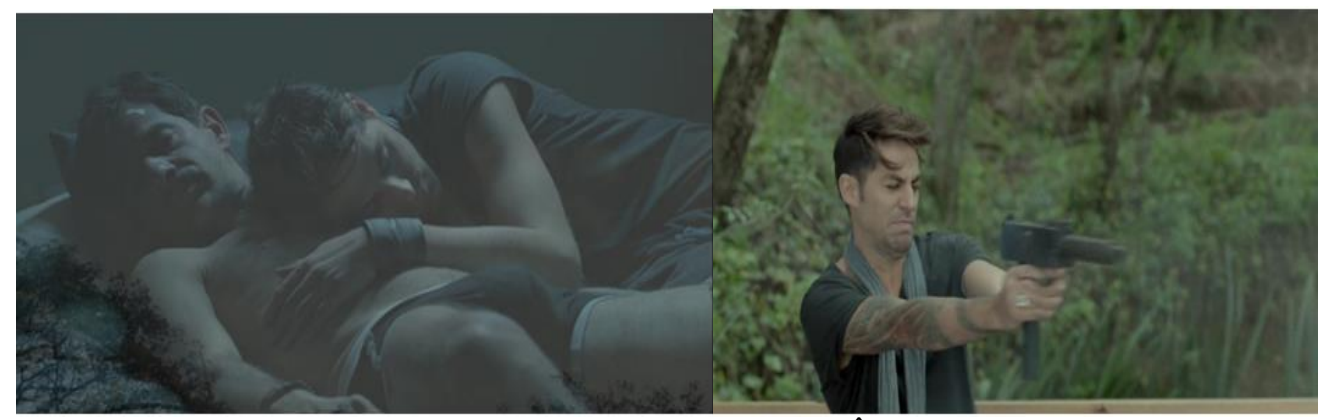

Figura 2: Subversão da matriz heteronormativa

Figura 3 - Ênfase em masculinidade

Nesse cuidado que Sandro proporciona a Evo, acontece uma noite de prática sexual. Porém, Evo acorda desorientado e não se lembra do que ocorreu durante a madrugada. Eles vão tomar café da manhã juntos e Sandro se refere ao sexo que ocorreu durante a madrugada, Evo entra em pânico como se a prática homossexual abalasse seu gênero (BUTLER, 1993).

\footnotetext{
-Sandro (bravo): Fizemos amor três vezes à noite.

-Evo: O que?

-Sandro: Três vezes.

-Evo: Feche essa boca perversa. Estou dizendo que isso é impossível.

-Sandro: Três vezes, sacana. Não é impossível quando há amor.

-Evo: Em seus sonhos [...] porque, para começar, eu não saberia nem o que enfiar em qual buraco. Eu não tenho o gene gay.

-Sandro: Não há o gene gay. É uma preferência sexual. E mais, é uma preferência temporal. [...] Dizer que alguém é gay ou hétero é exagerar. O que se deveria dizer é: "hoje estou gay. Ontem estive sendo hétero". (Trecho 2)
}

No começo do diálogo, Evo reproduz uma ordem de discurso biologizante da sexualidade enfatizando "Eu não tenho o gene gay". Mas no último texto de Sandro, a ruptura com a heteronormatividade hegemônica é evidente. Há uma crítica à visão essencialista e biologizante da sexualidade de modo que esta é uma construção cultural e normativa e que pode ser desnaturalizada ao demonstrar a fluidez sexual, ou seja, queering (desestabilizando) 
a prática sexual (BUTLER, 1993, 2003; MISKOLCI, 2009; SOUZA; COSTA; PEREIRA, 2015).

Após a crise com a comunidade LGBT, Evo se afasta do mundo da moda e vai para a casa de sua mãe como refúgio. Evo e a mãe assistem vídeos da infância dele brincando com roupas e acessórios femininos e conversam:

\begin{abstract}
-Evo: Mamãe, não sou gay.
-Mãe: Ah amor, eu já sabia.

-Evo: Mas também não sou um impostor, mamãe [...] eu queria entregar meu coração às sedas, aos acessórios, aos babados. E, bem, desde pequeno, começaram a dizer que eu era gay.

-Mãe: E você aproveitou os privilégios de parecer gay, de andar borboleteando e gesticulando.

-Evo: sim, e de não precisar falar como um soldado raso. [...] ter de usar cinza, azul... ou bege. Bem também descobri que podia me aproximar das mulheres sendo amiga delas [...] Até que esse terrorista, o maldito de leque vermelho me disse que tenho que ser o mesmo por dentro e por fora, mamãe. Imagine, mamãe! Ser cem por cento puro, vinte e quatro horas por dia, de hoje até a eternidade. (Trecho 3)
\end{abstract}

Nesse trecho, há uma ambivalência quanto à heteronormatividade em sua prática discursiva: ao mesmo tempo que afirma não ser gay reforçando a heteronormatividade, mas também não afirma ser heterossexual (implícito); ele subverte a heteronormatividade com o discurso da moda enquanto forma de expressão e de desidentificação com os padrões e estereótipos construídos em torno do gênero, desestabilizando o binário hegemônico sexual "ser cem por cento puro, vinte e quatro horas por dia" e de gênero "andar borboletando e gesticulando".

Depois de praticamente um mês longe do mundo da moda, Evo liga para Alva que conta que está na inauguração da semana internacional de moda. Ele desabafa e pede desculpa por arruinar o império. Ela conta que vão fazer o desfile sem ele. Daí, ele reage "sem mim", se disfarça e vai para o desfile. Nos bastidores ele vê Sandro e Vivi se beijando. Sandro é quem está produzindo o desfile e Vivi é a modelo principal. Começa o desfile com a temática da diversidade sexual: relações heterossexuais, homossexuais e bissexuais são exaltadas no palco. Então, aparece a cena em que Sandro e Evo fazem amor (gravada pelos documentaristas):

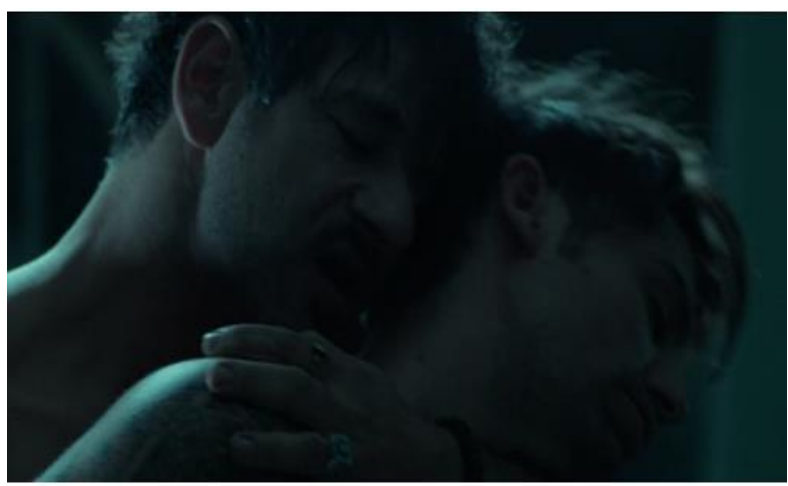

Figura 4 - Homossexualidade midiática

Evo assistindo fica espantando "Esse não sou eu". A plateia aplaude. Evo pergunta a Sandro se é uma montagem. Daí, os documentaristas corroboram que não. Vivi diz que não se preocupa, que é "super cabeça aberta". A crise de identidade de Evo é explicada, pois o nosso senso de ego é ligado ao social pelas interpelações discursivas (BUTLER, 2003, 1993). Evo começa a se lembrar do sexo. No final do desfile, que foi sucesso, Evo decide entrar no palco 
e leva Sandro junto com ele. Os dois entram de mãos dadas e são aplaudidos como um modo de publicizar e politizar o relacionamento e de desafiar a heteronormatividade (BUTLER, 2003).

No final do filme, evidencia-se a bissexualidade e as relações poliamorosas em que os três se casam. Desse modo, várias práticas sociais hegemônicas são contestadas nessa cena: a sexualidade não é simplesmente uma categoria estável, mas uma narrativa, ela pode ir além do binário desestabilizando a heteronormatividade, pois a bissexualidade desfaz a orientação sexual questionando a dualidade hétero-homo (GARBER, 1995); há um casamento diferente das convenções, envolvendo dois homens e uma mulher que se relacionam entre si, outra forma de subverter a rigidez do binário sexual.

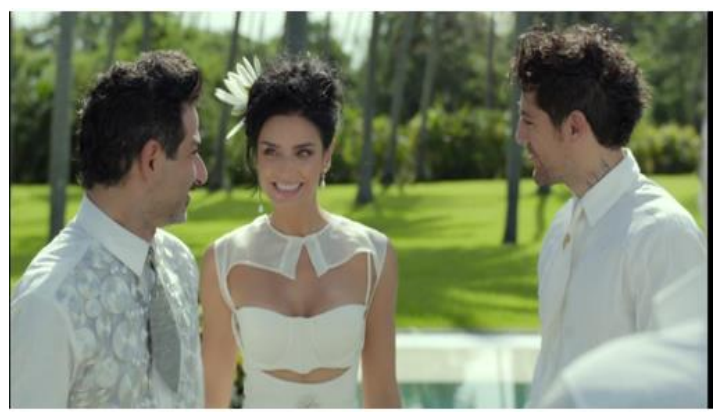

Figura 5 - Subversão social

4.3 "Às vezes eu me pergunto: Mas para quê, Evaristo? Por que não se tornou boxeador, como seu pai?": a reprodução e a subversão do discurso binário de gênero nas relações sociais de trabalho

Nessa seção, recorremos à análise textual da ACD para analisar a reprodução e a subversão do discurso binário de gênero nas relações sociais de trabalho. Para Hirata e Kergoat (2007), existe uma divisão sexual do trabalho que, historicamente, designou os homens à esfera produtiva e as mulheres à esfera reprodutiva de modo que as funções desempenhadas por eles possuem mais valor social adicionado, como políticos, religiosos, militares etc. No trecho 4, essa divisão é evidenciada pelo vocabulário.

Às vezes eu me pergunto: Mas para quê, Evaristo? Por que não se tornou boxeador, como seu pai? Ou sacerdote, como o Papa Francisco? Ou líder sindical? Ou ditador? Ou algo parecido? (Trecho 4)

As ocupações citadas por Evaristo em seu momento de reflexão, "boxeador", "sacerdote", "líder sindical" e "ditador", são todas funções designadas historicamente aos homens. A própria reflexão de Evaristo faz referência às ocupações no masculino e as liga a pessoas desse gênero, como seu "pai" e o "Papa Francisco", enquanto se questiona sobre sua profissão de estilista que, por sua vez, é associada ao gênero feminino.

Guiraldelli (2012) afirma que, mesmo que este seja um fenômeno complexo no qual há suposições de que a divisão sexual do trabalho teria um fim na contemporaneidade, a indústria da confecção é uma das ocupações reconhecidas como redutos femininos, o que demonstra a fragilidade das suposições anteriores. Assim, nessa separação entre profissões, o protagonista Evo, que desde criança sempre se identificou com o fazer próprio da indústria da confecção, busca performar o gênero feminino, como nos gestos de suas mãos, na forma de andar, nos movimentos com a cabeça e com o jogo de cabelo, ou seja, um corpo masculino fazendo gênero feminino. Mostrando como o gênero é performado, é prática, ele subverte o discurso binário de gênero, ao ensinar uma modelo durante uma prova de roupas a desfilar de modo elegante e erectus (BUTLER, 2003). 
Ainda no âmbito profissional, podemos analisar a performance de gênero de Alva, sócia de Evaristo, cujo apelido é Biscoito. Observe o diálogo que segue no Trecho 5:

\author{
-Alva: Maldita sacana invejosa! \\ -Evo: Não fume no carro, por favor, Biscoito! \\ -Alva: Evaristo, você não entende o que é um boicote à grife, certo? Significa \\ fechar todas as lojas, fechar a oficina, depois de dez anos de sacrifício. \\ -Evo: Apague esse cigarro, Biscoito! \\ -Alva: Evo, acabo de pensar uma coisa pavorosa. Quantas mulheres você \\ traçou... \\ -Evo: Que modo horrível de falar. Não tracei senão trajes de alta moda, meu \\ amor (Trecho 5)
}

Em uma situação de crise nos negócios, com o possível boicote à grife diante das críticas à sexualidade de Evaristo, Alva utiliza um vocabulário que foge à polidez feminina e é repreendida por Evo que se aproxima do masculino pelo sexo, mas se afasta dele na polidez e na racionalidade. Enquanto Alva raciocinava, nervosa, pensando nas consequências para o negócio, Evo se demonstrou preocupado com a situação imediata em que ela fumava dentro do carro dele. Ela utiliza uma estrutura textual de enumeração para exemplificar o significado das consequências de algo que ele parecia não entender ou mesmo não dar a devida importância. Assim, Evo e Alva protagonizam práticas de gênero, subvertendo novamente o binário masculino e feminino.

Assim como Evo, por vezes, Alva performa o gênero masculino em sua profissão de gestora, profissão socialmente valorizada por atributos masculinos. Alva se veste sempre de tailler, usa cabelos presos, está sempre conectada às novas informações, possui uma postura firme de comando e demonstra se dedicar a pensar soluções racionais para manutenção do império que eles construíram. Na Figura 6, é possível observar o gesto e a postura de Alva como pessoa que teve uma ideia para solução dos problemas:

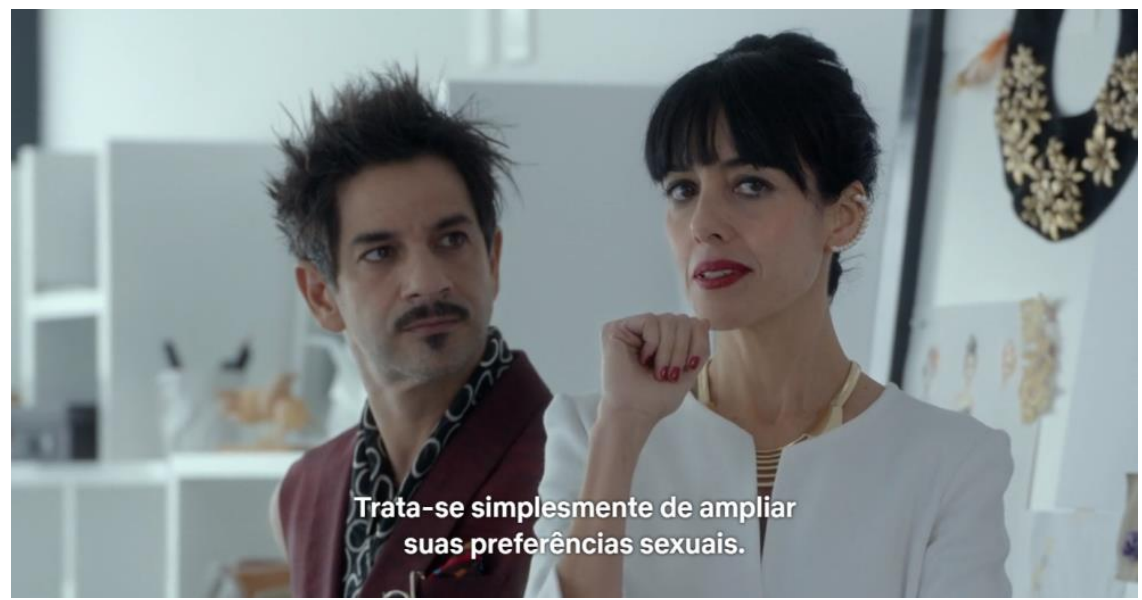

Figura 6 - Alva e a racionalidade

Analisando o ethos no texto, Evo se identifica como heterossexual tendo feito sexo com 322 mulheres, porém performa uma homossexualidade efeminada de modo a se distanciar de qualquer masculinidade. Ele diz à Karen (marido de Vivi):

Na próxima vida, quando eu for um homem, quero ser um macho feroz feito você. (Trecho 6)

Assim, constatamos um complexo processo em que as ordens de discurso que ligam a moda ao feminino e homossexual e a gestão ao masculino são naturalizadas, pois há 
reprodução dessa ordem. Contudo, é uma ordem que se transforma constantemente, pois em alguns momentos ela é subvertida, fazendo com que surjam novos arranjos nas relações de poder.

\section{Considerações Finais}

Neste artigo, percebemos que os filmes podem se constituir como formas de subversão das normas de gênero no contexto do trabalho ao possibilitar mudança social pelo/no discurso, uma vez que demonstra que as relações nas organizações e a construção de carreiras profissionais são interpeladas pelos dispositivos de gênero e sexualidade. Percebemos que o contexto do trabalho não é assexuado, racional e cartesiano, como preconizado por epistemologias funcionalistas. Ao apresentar possibilidades alternativas de vida social organizada, os filmes podem auxiliar na desconstrução de estereótipos e preconceitos relacionados à sexualidade e ao binarismo de gênero no contexto das organizações. Contudo, percebemos que esses mesmos filmes podem também se constituir como formas de reprodução dessas normas, quando não problematizam as diversas hierarquias de gênero e apresentam de forma estereotipada e naturalizada as masculinidades e feminilidades.

Assim, nosso objetivo foi analisar a reprodução e a subversão dos binários de gênero e de sexualidade no filme "Macho". Para tanto, discorremos sobre a constituição do sujeito e resistência em uma perspectiva feminista e sobre a reprodução e a subversão da matriz heteronormativa. Nossa contribuição teórica envolveu autores que abordam essa temática em uma perspectiva pós-estruturalista, feminista e queer, especialmente Judith Butler, ainda pouco utilizada nos estudos organizacionais brasileiros, mas que têm sido apropriada pelas ciências humanas e ciências sociais. Essa perspectiva foi utilizada com base nos princípios e na metodologia da análise crítica do discurso propostos por Normam Fairclough, o que se mostra coerente haja vista sua preocupação com os processos de reprodução e mudança social.

Essa abordagem se mostrou interessante para compreender a dinâmica de gênero e da sexualidade nas relações sociais e nas organizações, haja vista que usualmente a gestão é considerada uma atividade masculina e heteronormativa com pouco espaço para performances de gênero subversivas. Contudo, conforme mostramos com a análise do filme "Macho", as práticas de gestão bem como as práticas de sexualidade e de gênero podem e devem ser desessencializadas e historicizadas mostrando seu caráter ambivalente em que feminino e masculino se sobrepõem, separam-se, contestam-se em meio às relações de poder e em meio às ordens de discurso, evidenciando a reprodução ou a subversão do status quo. Com a desconstrução dessa polarização (feminino versus masculino; homossexual versus heterossexual), percebemos outras realidades organizacionais possíveis considerando toda a complexidade social, o que fomenta outras práticas de resistências frente a variados modos de opressão e dominação.

A sexualidade se mostra complexa frente às variadas ordens de discursos e sujeitos sociais, sendo influenciada pela família, pela mídia, pela biologia, pelas relações sociais de trabalho, por movimentos sociais, entre outras instâncias reprodutoras da heteronormatividade e do binário de gênero. Todavia, como o filme demonstra, a sexualidade também não é uma categoria estável ou rígida e pode ser subvertida na mesma rede de poder em que é reproduzida. Ela é representada e significada usualmente pela dicotomia heterossexualhomossexual que é questionada com a subversão de uma convenção social: o casamento 
bissexual. Isso nos mostra que a sexualidade não se trata de uma categoria estável mas que pode mudar durante a vida, traduzindo-se em uma narrativa, conforme defende Garber (1995).

Desse modo, a heteronormatividade e os estereótipos de gênero, dados às determinadas profissões ou determinados setores, não se sustentam, pois, como mostramos, as identidades não são estáveis de modo que os sujeitos podem subverter as normas mesmo agindo sem intenção considerando que diferentes corpos fazem diferentes gêneros em uma estrutura espacial e temporal. 


\section{REFERÊNCIAS}

ARAÚJO, F. F.; TOMEI, P. A. A ética corporativa e o cenário competitivo: uma análise dos dilemas éticos nas relações de trabalho contemporâneas a partir do filme "o corte" (Le Couperet). Revista Pensamento Contemporâneo em Administração, v. 6, n. 3, p. 121-145, 2012.

BENDL, R; FLEISCHMANN, A.; WALENTA, C. Diversity management discourse meets queer theory. Gender in management: an international journal, v. 23, n. 6, p. 382-394, 2008.

BUTLER, J. Bodies that matter: on the discursive limits of "sex". Routledge: New York, 1993.

Problemas de gênero: feminismo e subversão da identidade. Rio de Janeiro: Civilização brasileira, 2003.

Undoing Gender. Routledge: New York, 2004.

CARRIERI, A. P.; AGUIAR, A. R. C.; DINIZ, A. P. Reflexões sobre o indivíduo desejante e o sofrimento no trabalho: o assédio moral, a violência simbólica e o movimento homossexual.

Cad. EBAPE.BR, v. 11, n. 1, p. 165-180, 2013.

DÍAZ, E. A filosofia de Michel Foucault. São Paulo: Editora Unesp, 2012.

FAIRCLOUGH, N. Discurso e mudança social.Brasília: UnB, 2001.

Analysing discourse: textual analysis for social research. London: Routledge, 2003.

FERRAZ, D.L.S. et al. Ideologia, subjetividade e afetividade nas relações de trabalho: análise do filme "Que horas ela volta?". Revista Brasileira de Estudos Organizacionais, v. 4, n. 1, p. 252-278, 2017.

FOUCAULT, M. Vigiar e Punir: nascimento da Prisão. Petrópolis: Vozes, 1987

História da sexualidade I: a vontade de saber. 13. edição. Rio de Janeiro: Graal,

1988.

Microfísica do poder. 28. ed. Rio de Janeiro: Paz e Terra, 2014.

GARBER, M. Vice-versa: bissexualidade e o erotismo da vida cotidiana.Rio de Janeiro: Record, 1995.

HARDING, N.; FORD, J.; FOTAKI, M. Is the 'F'-word still dirty? A past, present and future of/for feminist and gender studies in Organization. Organization, v. 20, n. 1, p. 51-65, 2012.

HARDY, C. Researching organizational discourse. International Studies of Management \& Organization, v. 31, n. 3, p. 25-47, 2001.

HUCZYNSKI, A.; BUCHANAN, D.. Theory from fiction: A narrative process perspective on the pedagogical use of feature film. Journal of Management Education, v.

28, n. 6, p. 707-726, 2004.

LIONÇO, T.; DINIZ, D. Homofobia, silêncio e naturalização: por uma narrativa da diversidade sexual. Psicologia Política, v. 8, n. 16, p. 307 - 324, 2008

MACHADO, D. Q.; IPIRANGA, A. S. R.; MATOS, F. R. N. "Quero matar meu chefe": retaliação e ações de assédio moral. Revista Pretexto, v. 14, n. 1, p. 52-70, 2013.

MACHO. Direção de Antonio Serrano Argüelles. México: Astillero Films, 2016. DVD (90 min.): son., color.

MARIANO, S. A. O sujeito do feminismo e o pós-estruturalismo. Estudos Feministas, v. 13, n. 3, p. 483-505, 2005.

MEDEIROS, C. R. O.; VALADÃO JÚNIOR, V. M.; POSSAS, M. C. "Quem mais veste Prada?": psicopatas corporativos e assédio moral no trabalho. Revista ADM.MADE, v. 19, n. 1, p. 102-122, 2015.

MÉLlO, R. P. Corpos, heteronormatividade e performances híbridas. Psicologia \& Sociedade, v. 24, n. 1, p. 197-207, 2012. 
MELO, I. F. Análise do discurso e análise crítica do discurso: desdobramentos e intersecções.

Revista Eletrônica de Divulgação Científica em Língua Portuguesa, Linguística e Literatura, ano 5, n. 11, s/p, 2009.

MISKOLCI, R. A teoria queer e a sociologia: o desafio de uma analítica da normalização. Sociologias, ano 11, n. 21, p. 150-182, 2009.

Teoria queer: um aprendizado pelas diferenças. Belo Horizonte: Autêntica, 2012.

MORAES, A.F.G.; GOMES, D.C.; HELAL, D.H. Brazilian Jeitinho and Culture: An Analysis of the Films Elite Squad 1 and 2. Revista de Administração Mackenzie, v. 17, n. 3, p. 84-104, 2016.

PANAYIOTOU, A. "Macho" managers and organizational heroes: competing masculinities in popular films. Organization, v. 17, n. 6, p. 659-683, 2010.

Spacing gender, gendering space: a radical "strong plot" in film. Management Learning, v. 46, n. 4, p. 427-443, 2014.

PENAFRIA, M. Análise de filmes: conceitos e metodologia(s). In: CONGRESSO DA ASSOCIAÇÃO PORTUGUESA DE CIÊNCIAS DA COMUNICAÇÃO, 6., 2009. Anais... Lisboa: SOPCOM, 2009.

PETERS, M. Pós-estruturalismo e filosofia da diferença. Belo Horizonte: Autêntica, 2000. PINO, N. P. A teoria queer e os intersex: experiências invisíveis de corpos des-feitos. Cadernos Pagu, Campinas, n. 28, p. 149-174, 2007.

RESENDE, V. M.; RAMALHO, V. Análise de discurso crítica. São Paulo: Contexto, 2006. RICH, A. Heterossexualidade compulsória e existência lésbica. Bagoas - estudos gays: gêneros e sexualidades, Natal, v. 4, n. 5, p. 17 - 44, 2010

SOUZA, E. M. et al. A analítica de Foucault e suas implicações nos Estudos Organizacionais sobre poder. Organizações \& Sociedade, v. 13, n. 36, p.13-25, 2006.

SOUZA, E. M. A Teoria Queer e os Estudos Organizacionais: Revisando Conceitos sobre Identidade. Rev. adm. contemp., Curitiba , v. 21, n. 3, p. 308-326, 2017.

SOUZA,E. M.; CARRIERI, A. P. A analítica queer e seu rompimento com a concepção binária de gênero. Revista de Administração Mackenzie, v. 11, n. 3, pp. 46-70, 2010.

SOUZA, E. M.; MACHADO, L. D.; BIANCO, M. F. O homem e o pós-estruturalismo foucaultiano: implicações nos estudos organizacionais. Organizações \& Sociedade, v. 15, n .47, p. 71-86, 2008.

; SOUZA, S. P.; SILVA, A. R. L. O pós-estruturalismo e os estudos críticos de gestão: da busca pela emancipação à constituição do sujeito. Revista de Administração Contemporânea, Curitiba, v. 17, n. 2, p. 198-217, 2013.

; PEREIRA, S. J. Nunes. (Re)Produção de heterossexismo e heteronormatividade nas relações de trabalho: a discriminação de homossexuais por homossexuais. Revista de Administração Mackenzie, v. 14, n.4, p. 76-105, 2013.

; COSTA, A. S. M.; PEREIRA, S. J. N. A organização (in)corporada: ontologia organizacional, poder e corpo em evidência. Cadernos Ebape.BR, Rio de Janeiro, v. 13, n. 4, p. 727-742, 2015.

THOMAS, R.; DAVIES, A. What have the feminist done for us? Feminist theory and organizational resistance. Organization, v. 12, n. 5, p. 711-740, 2005.

WELZER-LANG, D. A construção do masculino: dominação das mulheres e homofobia. Estudos Feministas, v. 9, n. 2, p. 460-482, 2001.

ZANELLO, V. Saúde mental, gênero e dispositivos: cultura e processos de subjetivação. Curitiba: Appris, 2018. 